\title{
Structural analysis of DNA and RNA interactions with antioxidant flavonoids
}

\author{
C.D. Kanakis ${ }^{\text {a }}$, Sh. Nafisi ${ }^{\text {b }}$, Mehdi Rajabi ${ }^{\text {b }}$, Azadeh Shadaloi ${ }^{\text {b }}$, P.A. Tarantilis ${ }^{\text {a }}$, \\ M.G. Polissiou ${ }^{\mathrm{a}}$, J. Bariyanga ${ }^{\mathrm{c}}$ and H.A. Tajmir-Riahi ${ }^{\mathrm{d}, *}$

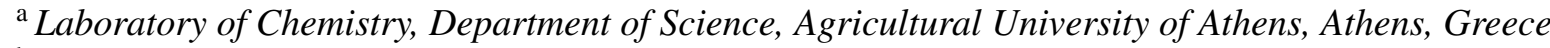 \\ ${ }^{\mathrm{b}}$ Department of Chemistry, Azad University, Central Tehran Branch (IAUCTB), Tehran, Iran \\ ${ }^{\mathrm{c}}$ Department of Chemistry, University of Hawaii - West O'ahu, Pearl City, HI, USA \\ ${ }^{\mathrm{d}}$ Department of Chemistry-Biology, University of Québec at Trois-Rivières, TR, Québec, QC, Canada
}

\begin{abstract}
Flavonoids are natural polyphynolic compounds with major antioxidant activity that can prevent DNA damage. The anticancer and antiviral activities of these natural products are attributed to their potential biomedical applications. In this review we are examining how the antioxidant flavonoids bind DNA and RNA and what mechanism of action is involved in preventing DNA damage. Detailed spectroscopic data on the interactions of morin (mor), apigenin (api), naringin (nar), quercetin (que), kaempferol (kae) and delphinidin (del) with DNA and transfer RNA in aqueous solution at physiological conditions were analysed. The structural analysis showed flavonoids mainly intercalate into DNA and RNA duplexes with minor external binding to the major or minor groove and the backbone phosphate group with overall binding constants for DNA adducts $K_{\text {mor }}=5.99 \times 10^{3} \mathrm{M}^{-1}, K_{\text {api }}=7.10 \times 10^{4} \mathrm{M}^{-1}$, and $K_{\text {nar }}=3.10 \times 10^{3} \mathrm{M}^{-1}, K_{\text {que }}=7.25 \times 10^{4} \mathrm{M}^{-1}$, $K_{\mathrm{kae}}=3.60 \times 10^{4} \mathrm{M}^{-1}$ and $K_{\text {del }}=1.66 \times 10^{4} \mathrm{M}^{-1}$, and for tRNA adducts $K_{\mathrm{mor}}=9.15 \times 10^{3} \mathrm{M}^{-1}, K_{\text {api }}=4.96 \times 10^{4} \mathrm{M}^{-1}$, and $K_{\text {nar }}=1.14 \times 10^{4} \mathrm{M}^{-1}, K_{\text {que }}=4.80 \times 10^{4} \mathrm{M}^{-1}, K_{\text {kae }}=4.65 \times 10^{4} \mathrm{M}^{-1}$ and $K_{\text {del }}=9.47 \times 10^{4} \mathrm{M}^{-1}$. The stability of adduct formation is in the order of que $>$ api $>$ kae $>$ del $>$ mor $>$ nar for DNA and del $>$ api $>$ que $>$ kae $>$ nar $>$ mor for tRNA. Low flavonoid concentration induces helical stabilization, whereas high pigment content causes helix opening. Flavonoids induce a partial B to A-DNA transition at high pigment concentration, while tRNA remains in A-family structure upon flavonoid complexation. The antioxidant activity of flavonoids changes in the order delphinidin $>$ quercetin $>$ kaempferol $>$ morin $>$ naringin $>$ apigenin. The results show intercalated flavonoid molecule can act as an antioxidant and prevent DNA damage.
\end{abstract}

Keywords: DNA, tRNA, antioxidant, flavonoids, binding sites, binding constant, conformation, FTIR, UV-visible spectroscopy

\section{Abbreviations}

api: apigenin,

mor: morin,

nar: naringin,

que: quercetin,

del: delphinidin,

kae: kaempferol,

FTIR: Fourier transform infrared.

\footnotetext{
${ }^{*}$ Corresponding author: H.A. Tajmir-Riahi, Department of Chemistry-Biology, University of Québec at Trois-Rivières, TR, Québec, QC, G9A 5H7 Canada. E-mail: Heidar-ali.tajmir-riahi@uqtr.ca.
} 


\section{Introduction}

Oxidative stress in humans arises from an imbalance in the antioxidant status (reactive oxygen species versus defence and repair mechanisms). The essential features of oxidation via a free radical mediated chain reaction are initiation, propagation, branching and termination steps. The process may be initiated by the action of external agents such as heat, light or ionizing radiation, UV or by chemical initiation involving metal ions or metalloproteins. Among the endogenous defences are enzymes such as superoxide dismutase, catalase and glutathione peroxidase plus vitamin E, uric acid and serum albumins. When an excess of free radicals is formed they can overwhelm protective enzymes by oxidizing membrane lipids, cellular proteins, DNA and enzymes. Besides the endogenous defences, consumption of dietary antioxidants is also important [1]. Dietary antioxidants include ascorbate, tocopherols, carotenoids and flavonoids [2].

Flavonoids are ubiquitous in plants. They are rich in seeds, citrus fruits, olive oil, tea and vegetables. They are low molecular weight compounds composed of a three-ring structure with various substitutions. Several flavonoids have been reported to inhibit either enzymatic or nonenzymatic lipid peroxidation. It has been proposed that flavonoids react with lipid peroxyl radical (LOO') leading to the termination of radical chain reaction [3]. The autoxidation of linoleic acid and methyl linolate was inhibited by flavonoids such as fustin, catechin, quercetin, rutin, luteolin, kaempferol and morin [4]. Morin and kaempferol were the most inhibitory for the autoxidation of linoleic acid.

There is a relationship between the antioxidant activity of flavonoids and their structure [5]. The presence of an ortho-hydroxylation on the B-ring of the flavonoid molecule, the number of free hydroxyl groups, a C2-C3 double bond in the C-ring or the presence of a 3-hydroxyl (Fig. 1) is usually listed as a condition of antioxidant and antiradical activities [6].<smiles>O=c1c(O)c(-c2ccc(O)cc2O)oc2cc(O)cc(O)c12</smiles>

Morin<smiles>O=c1c(O)c(-c2ccc(O)cc2)oc2cc(O)cc(O)c12</smiles>

Kaempferol<smiles>O=c1cc(-c2ccc(O)cc2)oc2cc(O)cc(O)c12</smiles>

Apigenin<smiles>O=c1c(O)c(-c2ccc(O)c(O)c2)oc2cc(O)cc(O)c12</smiles>

Quercetin

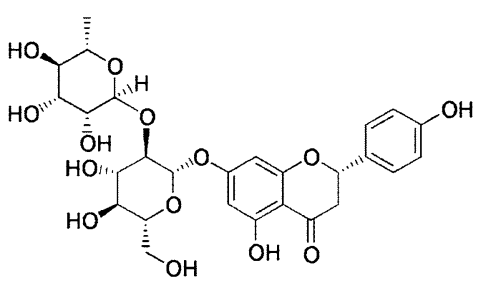

Naringin<smiles></smiles>

Delphinidin

Fig. 1. Chemical structures of flavonoids. 
Flavonoids have been found to have antiviral, antiproliferative, antiallergic, anticancer, antitumor and antiinflammatory effects [7-22]. Although it was initially hypothesized that the biological activity of flavonoids would be related to their antioxidant properties, available evidence from cell culture experiments suggested that many biological effects of flavonoids are related to their ability to modulate cell signaling pathways [22]. Flavonoids are also involved in vital DNA functions such as gene expression, gene transcription, mutagenesis, carcinogenesis and cell death [23-29]. They are a large family of compounds with common chemical structure [30], can intercalate DNA duplex and react with free radicals in order to protect DNA from oxidative damage [31,32]. Covalent bindings of quercetin to, DNA and protein have been recently reported [31-33]. Protection by quercetin and quercetin-rich fruit juice against induction of oxidative damage has been well demonstrated [34].

In this review the interactions of the flavonoids morin, apigenin, naringin, kaempferol, quercetin and delphinidin with DNA and tRNA in vitro with regard to their binding modes, stability and structural aspects, antioxidant activity and biological implications are reported.

\section{Materials and methods}

\subsection{Materials}

Apigenin, morin, naringin, quercetin, delphinidin and kaempferol were purchased from Sigma Chemical Company (St. Louis, MO, USA). Highly polymerised type I calf-thymus DNA sodium salt (7\% Na content) and yeast transfer RNA sodium salt were purchased from Sigma Chemical Co., and used as supplied. The absorbance at 260 and $280 \mathrm{~nm}$ was recorded, in order to check the protein content of DNA and tRNA solution. The $A_{260} / A_{280}$ ratios were 1.85 for DNA and 2.2 for tRNA showing that polynucleotides are sufficiently free from protein. Other chemicals were of reagent grade and used without further purification.

\subsection{Preparation of stock solutions}

DNA or tRNA sodium salt $(5 \mathrm{mg} / \mathrm{ml})$ was dissolved in distilled water with Tris/HCl buffer (pH 7.20) at $5^{\circ} \mathrm{C}$ for $24 \mathrm{~h}$ with occasional stirring to ensure the formation of a homogeneous solution. The final concentrations of the stock DNA and RNA solution were determined spectrophotometrically at $260 \mathrm{~nm}$ using molar extinction coefficient $\varepsilon_{260}=6600 \mathrm{~cm}^{-1} \mathrm{M}^{-1}$ (DNA) and $\varepsilon_{260}=9250 \mathrm{~cm}^{-1} \mathrm{M}^{-1}$ (RNA) (expressed as molarity of phosphate groups). The final concentration of the calf-thymus DNA solution was determined spectrophotometrically at $260 \mathrm{~nm}$ using molar extinction coefficient (expressed as molarity of phosphate groups) [35,36]. The average length of the DNA molecules, estimated by gel electrophoresis was 9000 base pairs (molecular weight $\sim 6 \times 10^{6} \mathrm{Da}$ ). The appropriate amounts of flavonoids $(0.1-12.5 \mathrm{mM})$ were prepared in distilled water-ethanol (50/50\%) and added dropwise to DNA or tRNA solution, in order to attain the desired pigment/polynucleotides $(\mathrm{P})$ molar ratios $(r)$ of $1 / 120$ to $1 / 1$ with a final DNA or RNA concentration of $6.25 \mathrm{mM}$ (phosphate). It should be noted that ethanol at $75 \%$ concentration facilitates B to A-DNA conformational transition, whereas at lower ethanol content (such as 50/50\% ethanol/water used here) does not effect DNA conformation [37,38]. The $\mathrm{pH}$ of the solutions was adjusted at $7.0 \pm 0.2$, using $\mathrm{NaOH}$ solution. 


\subsection{FTIR spectroscopic measurements}

Infrared spectra were recorded on a Nicolet Magna 750 FTIR spectrophotometer (DTGS detector, $\mathrm{Ni}$-chrome source and $\mathrm{KBr}$ beam splitter) with 100 scans and resolution of $4 \mathrm{~cm}^{-1}$. Spectra were collected and manipulated using the OMNIC (ver. 3.1) software supplied by the manufacturer. Spectra were recorded after $1 \mathrm{~h}$ of incubation, using $\mathrm{AgBr}$ windows. The difference spectra ((polynucleotide solution + flavonoid solution) - (polynucleotide)) were generated using bands at $968 \mathrm{~cm}^{-1}$ (DNA) and $867 \mathrm{~cm}^{-1}$ (RNA) as internal standard [39,40]. These vibrations are due to sugar C-C stretching modes and exhibit no spectral changes upon flavonoid-polynucleotide interaction.

\subsection{Absorption spectroscopy}

The UV-Vis spectra were recorded on a Jasco UV-Vis, V-550 spectrophotometer with a slit of $2 \mathrm{~nm}$ and scan speed of $400 \mathrm{~nm} \mathrm{~min}^{-1}$. Quartz cuvettes of $1 \mathrm{~cm}$ were used. The absorbance assessments were performed at $\mathrm{pH} 7.3$ by keeping the concentration of DNA or tRNA constant $(0.25 \mathrm{mM})$, while varying the concentration of flavonoids $(0.005-0.3 \mathrm{mM})$.

The values of the binding constants $K$ were obtained according to the methods reported [41,42]. To calculate the flavonoid-polynucleotide binding constant, the data are treated according to the following equations:

$$
\begin{aligned}
& \text { polynucleotides }+ \text { flavonoid } \leftrightarrow \text { polynucleotides-flavonoid, } \\
& K=(\text { polynucleotides-flavonoid complex }) /(\text { polynucleotides })_{\text {free }}(\text { flavonoid })_{\text {free }} .
\end{aligned}
$$

The values of the binding constants $K$ were obtained from the polynucleotides absorption at $260 \mathrm{~nm}$ according to the published methods [41,42], where the bindings of various ligands to hemoglobin were described. For weak binding affinities the data were treated using linear reciprocal plots based on the following equation:

$$
\frac{1}{A-A_{0}}=\frac{1}{A_{\infty}-A_{0}}+\frac{1}{K\left(A_{\infty}-A_{0}\right)} \frac{1}{C_{\text {ligand }}},
$$

where, $A_{0}$ is the absorbance of polynucelotides (DNA or RNA) at $260 \mathrm{~nm}$ in the absence of ligand, $A_{\infty}$ is the final absorbance of the ligated-DNA or RNA and A is the recorded absorbance at different ligand concentrations. The double reciprocal plot of $1 /\left(A-A_{0}\right)$ vs. $1 / C_{\text {ligand }}$ is linear and the binding constant $(K)$ can be estimated from the ratio of the intercept to the slope.

\section{Results and discussion}

\subsection{Flavonoid-DNA adducts}

Spectroscopic data indicated that morin, apigenin and naringin-DNA interactions might be complex, involving DNA grooves and $\mathrm{PO}_{2}$ group as well as intercalation [43-45]. Evidence for groove binding and $\mathrm{PO}_{2}$ interaction comes from the infrared spectroscopy, while UV-Vis results show some degree of drug intercalation. In the FTIR spectra of morin, apigenin and naringin-DNA, the guanine band at 


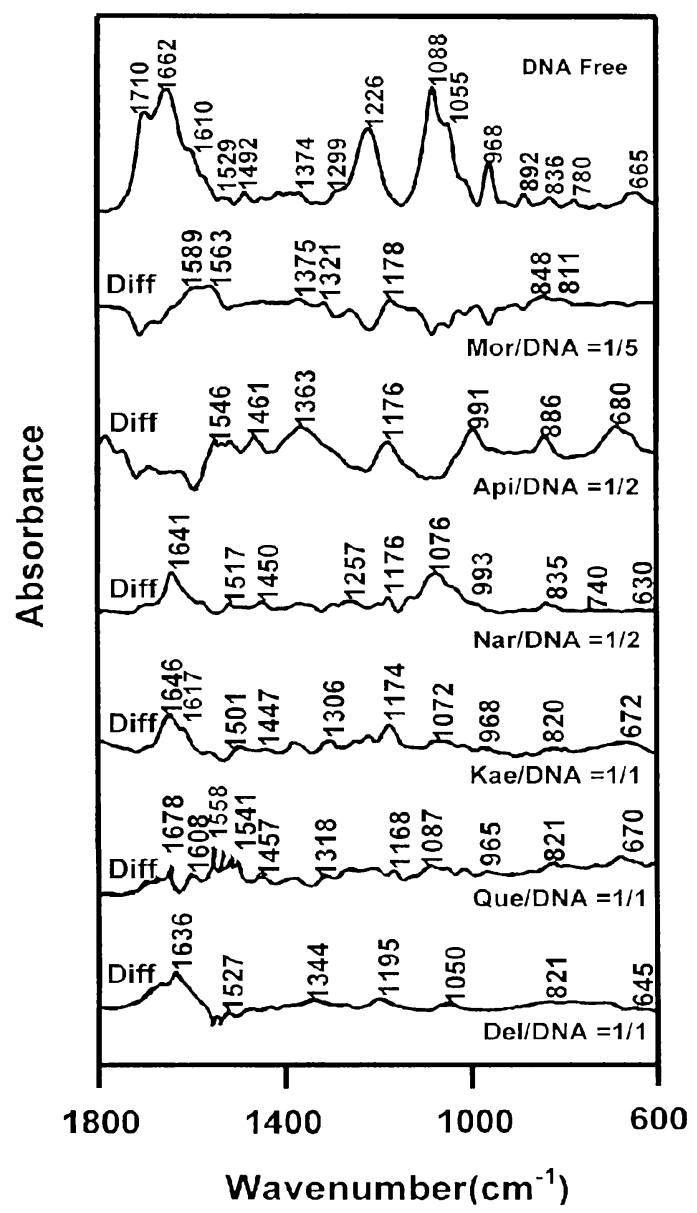

Fig. 2. Infrared absorption spectra of the free DNA (first curve) and difference spectra of flavonoid-DNA adducts (six curves) in aqueous solution at $\mathrm{pH} 7$ in the region of $1800-600 \mathrm{~cm}^{-1}$.

1710 shifted to $1714-1697 \mathrm{~cm}^{-1}$, the adenine band at $1610 \mathrm{~cm}^{-1}$ shifted to $1626-1614 \mathrm{~cm}^{-1}$, major intensity variations were observed for the backbone phosphate group at $1226 \mathrm{~cm}^{-1}$ (Fig. 2). The observed spectral changes can be due to interaction of morin, apigenin and naringin with guanine and adenine N7 and backbone phosphate group. The UV-Vis shows that at lower concentrations of morin and naringin, intercalation occurs with DNA duplex, while at higher concentrations, external binding is predominant (Fig. 3). For apigenin, intercalation occurs at all concentrations. Evidence for intercalation comes from a major reduction in the intensity of UV-Vis bands characteristics of flavonoid. The major intensity decrease of characteristic UV-Vis band at $254 \mathrm{~nm}$ (apigenin), is indicative of drug intercalation via DNA duplex (Fig. 3), while intensity increase of the bands at $266 \mathrm{~nm}$ (morin) and $267 \mathrm{~nm}$ (naringin) is indicative of interaction at higher concentrations (Fig. 3). The above results are consistent with Bible and Webb reports, which concluded that apigenin intercalates DNA duplex $[33,43,44]$.

Quercetin, kaempferol and delphinidin bind externally to DNA bases and the backbone $\mathrm{PO}_{2}$ group. Evidence for this comes from shifting of the guanine band at 1710 to $1706-1699 \mathrm{~cm}^{-1}$ and the intensity variations of the phosphate band at $1226 \mathrm{~cm}^{-1}$ (Fig. 2) [45]. The observed spectral changes are 


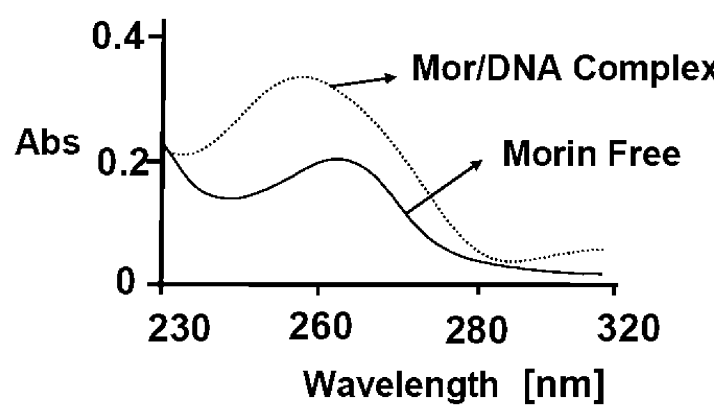

(A)

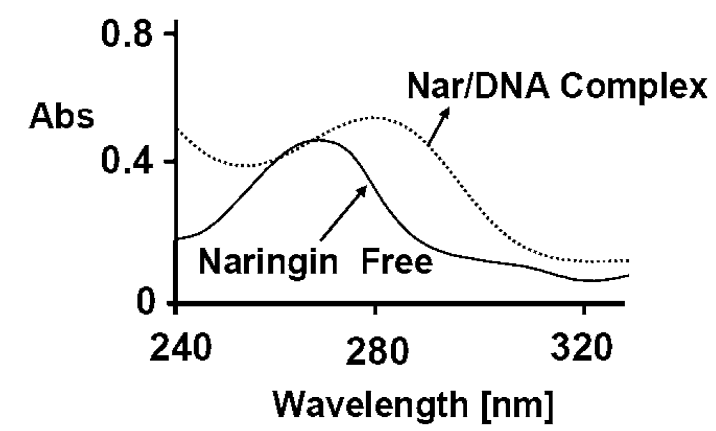

(C)

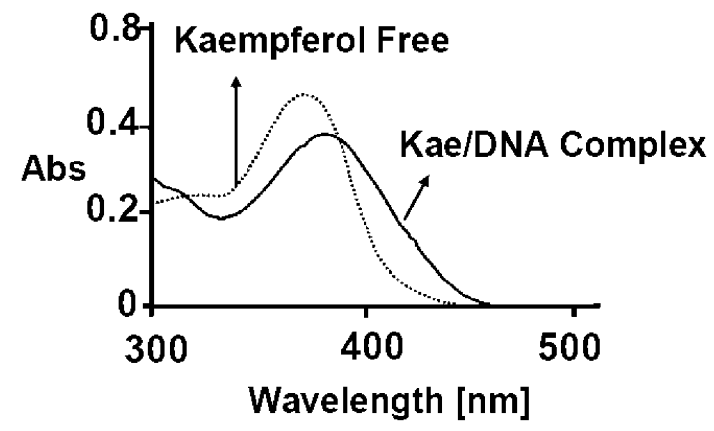

(E)

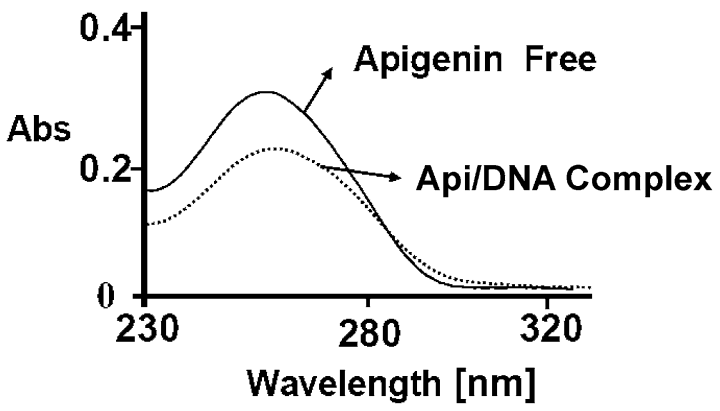

(B)

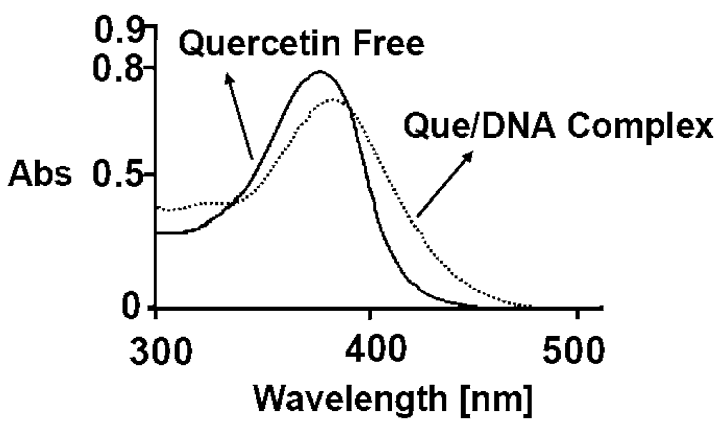

(D)

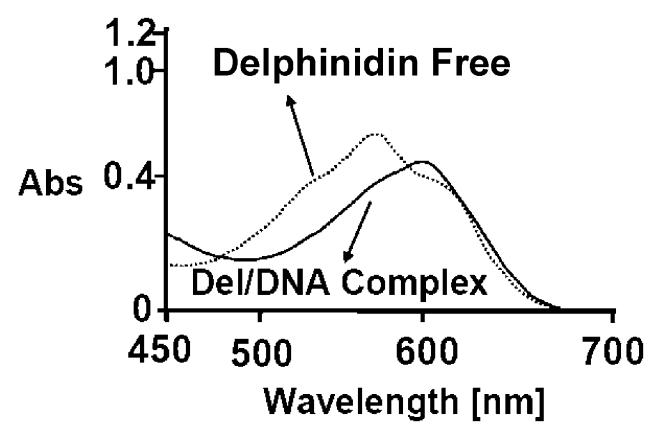

(F)

Fig. 3. UV-visible spectra characteristics of flavonoids and their DNA adducts for morin at $266 \mathrm{~nm}$ (A), apigenin at $254 \mathrm{~nm}$ (B), naringin at $267 \mathrm{~nm}(\mathrm{C})$, quercetin at $375 \mathrm{~nm}(\mathrm{D})$, kaempferol at $370 \mathrm{~nm}(\mathrm{E})$ and delphinidin at $576 \mathrm{~nm}(\mathrm{~F})$ with final DNA concentration of $0.25 \mathrm{mM}$.

due to an indirect interaction of flavonoids with guanine $\mathrm{N} 7$ and the backbone $\mathrm{PO}_{2}$ group (spectra not shown). However, some degree of pigment intercalation occurs with DNA duplex. Evidence for intercalation comes from a major reduction in the intensity of UV-Vis bands characteristic of flavonoids upon DNA interaction (Fig. 3). The major intensity decrease of characteristic UV-Vis band at $375 \mathrm{~nm}$ (quercetin), $370 \mathrm{~nm}$ (kaempferol) and $576 \mathrm{~nm}$ (delphinidin) is indicative of drug intercalation via DNA duplex (Fig. 3). It has been demonstrated that intercalation of flavone into DNA duplex causes major reduction in the intensity of the UV-Vis absorption band characteristics of flavones. This hypochromic shift indicates helical ordering of flavone in the DNA helix. The limitation on molecular movements of flavone causes a decrease in its ability to absorb light energy [46-48]. 


\subsection{Flavonoid-tRNA adducts}

Flavonoids bind tRNA via both external and intercalation modes. Evidence for external binding comes from infrared spectroscopy (Fig. 4), while UV-Vis results show some degree of pigment intercalation (Fig. 4).

At low pigment concentration $(r=1 / 120)$, no major morin and naringin-RNA interaction occurred as indicated by the minor shifting and decrease in the intensity due to bases and phosphate bands. However, at low apigenin concentration $(r=1 / 120)$, major decrease in the intensity of the bands can be related to apigenin intercalation into RNA. At high pigment concentrations, major spectral changes occurred for bases (mainly guanine) and back bone $\mathrm{PO}_{2}$ asymmetric stretching band (Fig. 4). The observed spectral changes can be due to interaction of morin, apigenin and naringin with bases mainly guanine, adenine N7 and backbone phosphate group [49].

The UV-Vis shows that apigenin intercalation occurs with RNA duplex, while for morin and naringin, external binding is predominant (Fig. 5). Evidence for intercalation comes from a major reduction in the intensity of UV-Vis bands characteristics of flavonoid. The major intensity decrease of character-

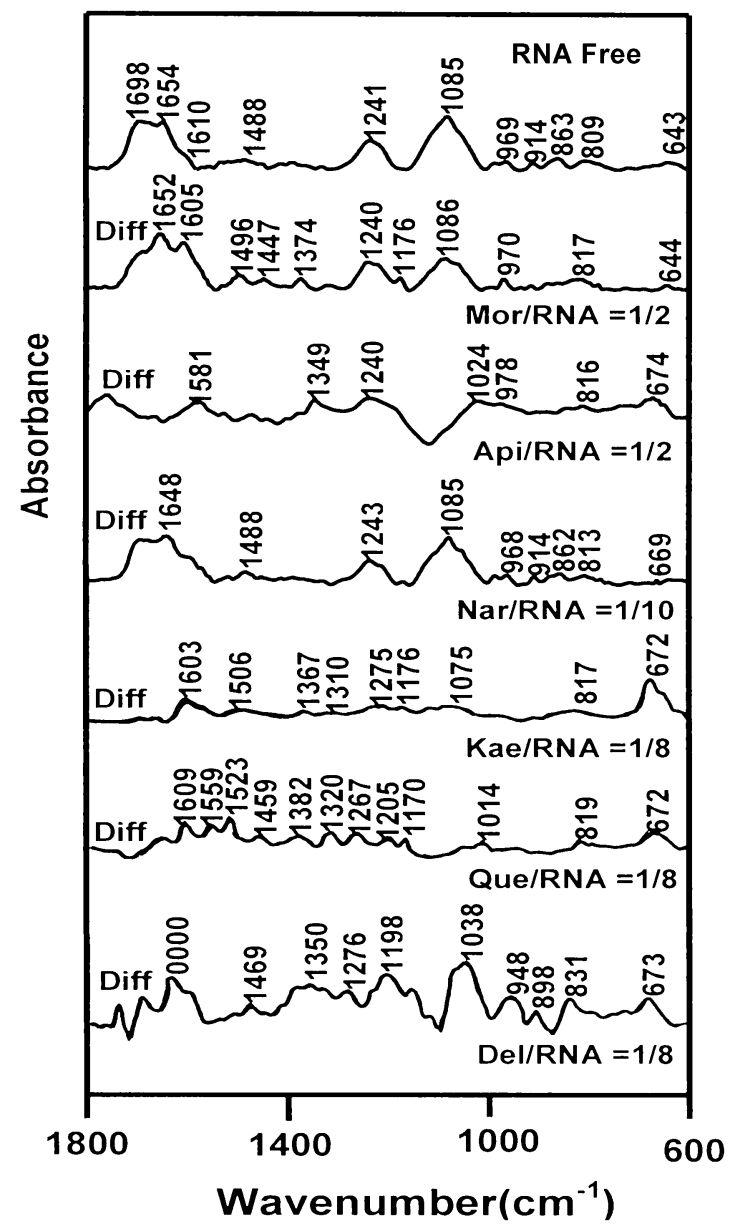

Fig. 4. Infrared absorption spectra of the free tRNA (first curve) and difference spectra of flavonoid-RNA adducts (six curves) in aqueous solution at $\mathrm{pH} 7$ in the region of $1800-600 \mathrm{~cm}^{-1}$. 


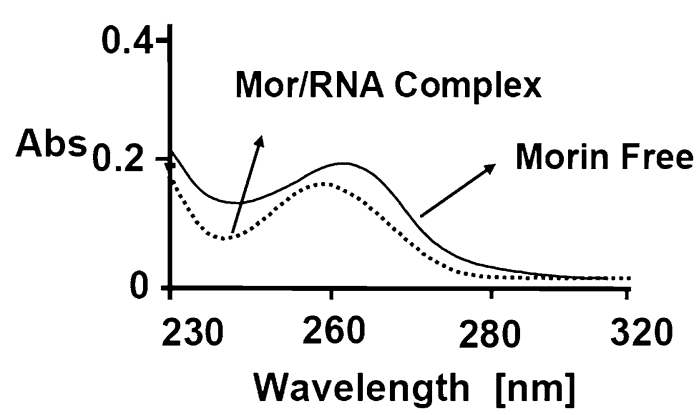

(A)

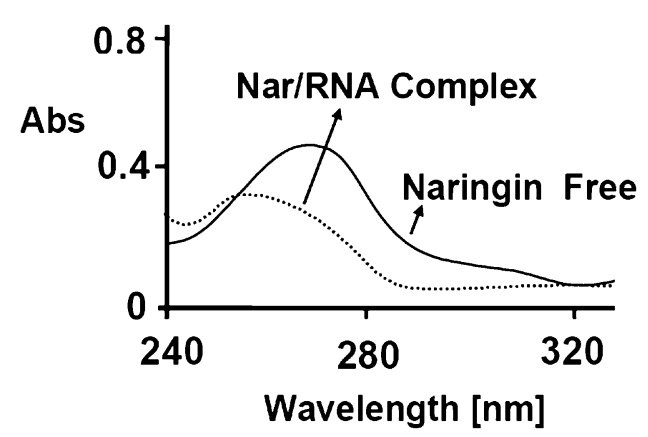

(C)

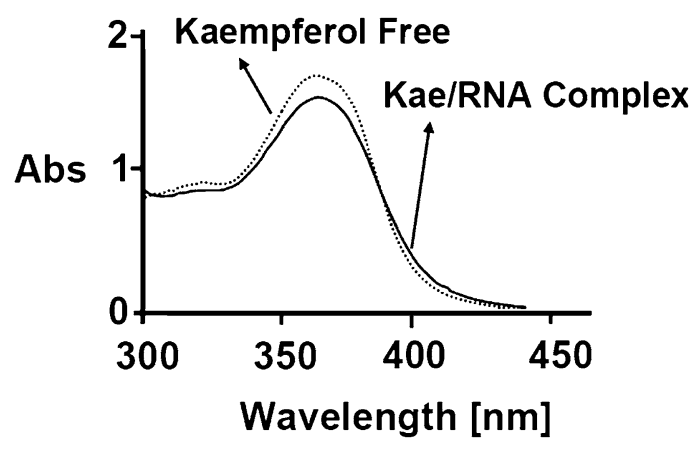

(E)

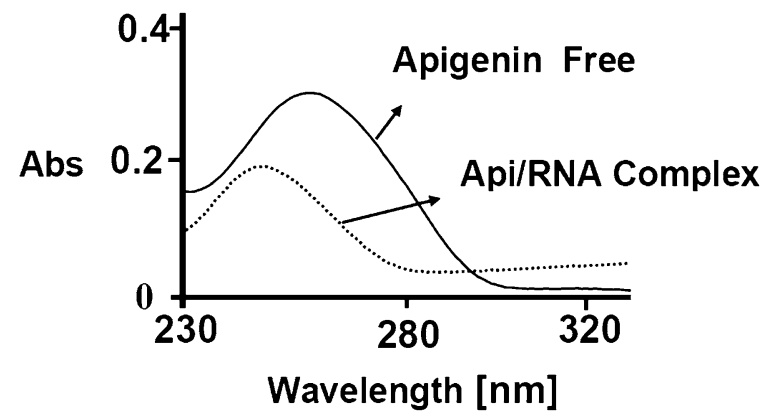

(B)

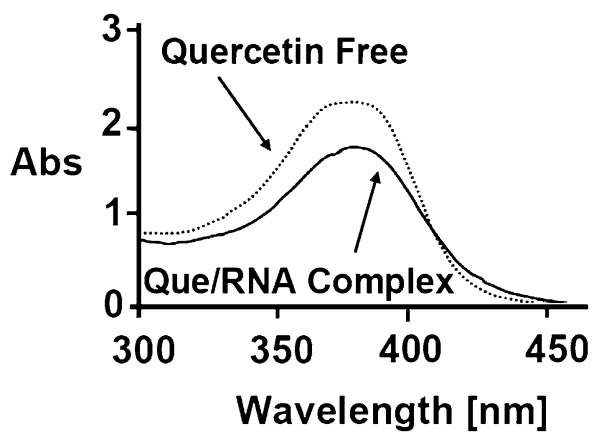

(D)

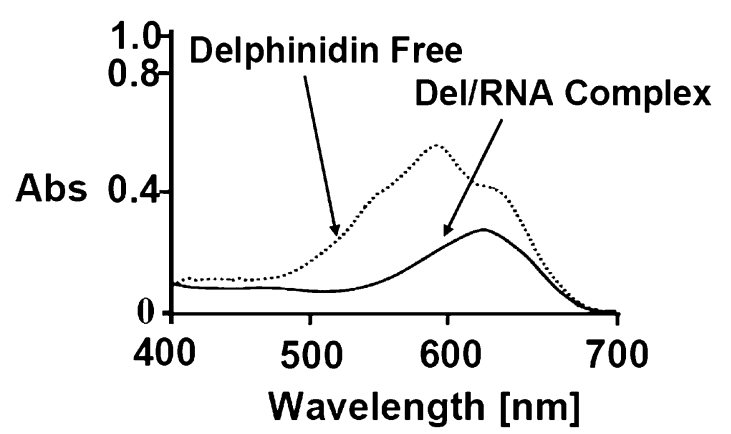

(F)

Fig. 5. UV-visible spectra characteristics of flavonoid and their tRNA adducts for morin at $266 \mathrm{~nm}$ (A), apigenin at $254 \mathrm{~nm}$ (B), naringin at $267 \mathrm{~nm}(\mathrm{C})$, quercetin at $375 \mathrm{~nm}(\mathrm{D})$, kaempferol at $370 \mathrm{~nm}(\mathrm{E})$ and delphinidin at $576 \mathrm{~nm}(\mathrm{~F})$ with final RNA concentration of $0.25 \mathrm{mM}$.

istic UV-Vis band at $254 \mathrm{~nm}$ (apigenin), is indicative of drug intercalation via RNA duplex (Fig. 5). Intercalation is also observed for the morin and naringin/RNA complexes. The decrease in intensity of the characteristic UV-Vis bands at $266 \mathrm{~nm}$ (morin) and $267 \mathrm{~nm}$ (naringin) is indicative of pigment intercalation via RNA duplex (Fig. 5).

The band at $1698 \mathrm{~cm}^{-1}$ in the free RNA spectrum, related to $\mathrm{C}=\mathrm{O}$ stretching vibrations of guanine and uracil bases exhibited shifting towards a lower frequency at $1695-1687 \mathrm{~cm}^{-1}$ upon quercetin, kaempferol and delphinidin complexation (Fig. 4). The backbone $\mathrm{PO}_{2}$ asymmetric stretching band at $1241 \mathrm{~cm}^{-1}$ showed some alterations in the spectra of flavonoid-RNA complexes. The spectral changes observed for the band at 1698 and $1241 \mathrm{~cm}^{-1}$ are due to some degree of drug interaction with guanine 
bases and the backbone phosphate group [50]. However, the major intensity decrease of the flavonoids characteristic UV-Vis bands at 375 (quercetin), 370 (kaempferol) and $576 \mathrm{~nm}$ (delphinidin) is indicative of drug intercalation via RNA duplex (Fig. 5). It has been demonstrated that intercalation of flavonoids into DNA duplex causes major reduction in intensity of the UV-Vis absorption band characteristics of flavones. This hypochromic shift indicates helical ordering of flavone in the tRNA helix [46-48].

\subsection{DNA and RNA conformations}

A partial B to A-DNA transition occurred upon flavonoid adduct formation at high drug concentrations. Evidence for this comes from the shift of the sugar-phosphate band at $836 \mathrm{~cm}^{-1}$ (B-DNA marker) towards a lower frequency with major reduction in its intensity. In the difference spectra of flavonoidDNA complexes $(r=1)$, the emergence of a new peak at about $820 \mathrm{~cm}^{-1}$ (A-DNA marker) is accompanied by a major loss of the intensity of the band at $836 \mathrm{~cm}^{-1}$ (B-DNA marker) [51,52]. Similarly, the other B-DNA marker band at 1710 shifted to $1706-1699 \mathrm{~cm}^{-1}$ upon drug complexation (Fig. 2). However, other B-DNA marker band at $1226 \mathrm{~cm}^{-1}$ showed no major shifting in the spectra of flavonoidDNA adducts. In a complete B-A transition, the B-DNA marker bands are observed at $1710-1700 \mathrm{~cm}^{-1}$, $1226-1240 \mathrm{~cm}^{-1}, 825-800 \mathrm{~cm}^{-1}$, respectively, and a new band appears at about $870-860 \mathrm{~cm}^{-1}$ (Fig. 2). The observed shifting for the bands at 836 and $1710 \mathrm{~cm}^{-1}$, is due to a partial reduction of the B-DNA towards A-DNA upon flavonoid complexation. The free tRNA is in A-conformation with characteristic infrared bands at 1698 (guanine), 1241 (phosphate), 867 and $809 \mathrm{~cm}^{-1}$ (phosphodiester) (Fig. 4). Although some of the ribose-phosphate vibrations are overlapped by flavonoid vibrations, the presence of the major bands at $1700-1687 \mathrm{~cm}^{-1}$ (guanine), $1240-1235 \mathrm{~cm}^{-1}$ (phosphate), $868-865 \mathrm{~cm}^{-1}$ (ribosephosphate) and $815-802 \mathrm{~cm}^{-1}$ (phosphodiester) are indicative of tRNA remaining in A-conformation upon flavonoid complexation (Fig. 4).

\subsection{Stability of flavonoid-DNA and flavonoid-tRNA adducts}

One binding constant was observed for the flavonoid-DNA and flavonoid-RNA complexes with $K_{\text {mor }}=5.99 \times 10^{3} \mathrm{M}^{-1}, K_{\text {api }}=7.10 \times 10^{4} \mathrm{M}^{-1}$, and $K_{\text {nar }}=3.10 \times 10^{3} \mathrm{M}^{-1}, K_{\text {que }}=7.25 \times 10^{4} \mathrm{M}^{-1}$, $K_{\text {kae }}=3.60 \times 10^{4} \mathrm{M}^{-1}$ and $K_{\text {del }}=1.66 \times 10^{4} \mathrm{M}^{-1}$ (Fig. 6 and Table 1 ). Similarly one binding constant was calculated for the pigment-tRNA adducts with $K_{\text {mor }}=9.15 \times 10^{3} \mathrm{M}^{-1}, K_{\text {api }}=4.96 \times 10^{4} \mathrm{M}^{-1}$, and $K_{\text {nar }}=1.14 \times 10^{4} \mathrm{M}^{-1}, K_{\text {que }}=4.80 \times 10^{4} \mathrm{M}^{-1}, K_{\text {kae }}=4.65 \times 10^{4} \mathrm{M}^{-1}$ and $K_{\text {del }}=9.47 \times 10^{4} \mathrm{M}^{-1}$ (Fig. 7 and Table 1). The stability of adduct formation is in the order of que $>$ api $>$ kae $>$ del $>$ mor $>$ nar for DNA and del $>$ api $>$ que $>$ kae $>$ nar $>$ mor for tRNA (Figs 6, 7 and Table 1). The larger $K$ value obtained for del-tRNA complexes can be due to the presence of a positive charge associated with delphinidin, which neutralizes the backbone phosphate negative charge (external binding) and brings additional stability for delphinidin-tRNA complexes. However, in the case of del-DNA adducts major ligand intercalation occurred, while less external binding is observed. This can be the reason why stability of del-RNA is larger than del-DNA complexes.

Morin contains 2, 4 adjacent hydroxyl groups that can easily form intermolecular hydrogen bonds. It has a greater density of negative charges which prevent strong interaction with DNA and RNA, its unusually low pKa of 3.5 , making it anionic at neutral $\mathrm{pH}$ and unlikely to make strong interaction with DNA and RNA duplex [33,53]. Apigenin presents a binding constant that is 10 times bigger than the morin and naringin which suggests the carbonyl groups of DNA and RNA bases have been involved in fairly strong hydrogen bonding with apigenin. Since apigenin is less water-soluble than the other two 


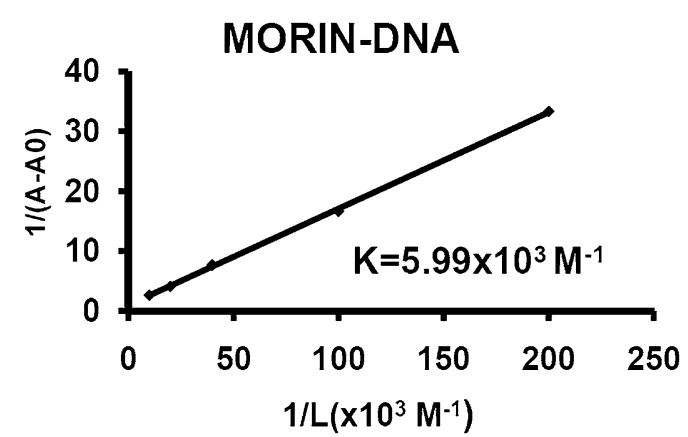

(A)

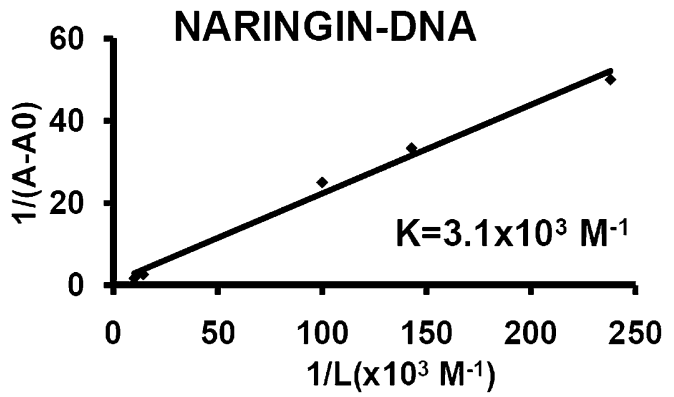

(C)

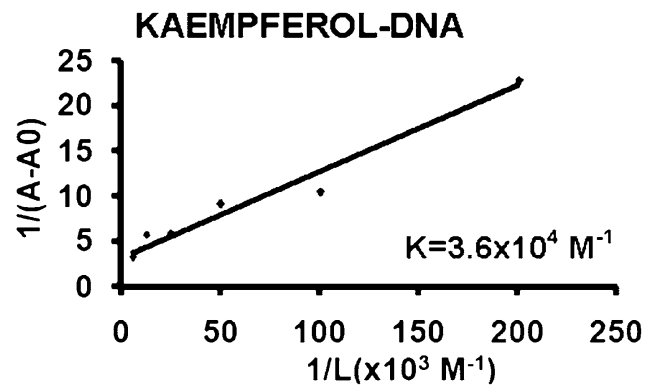

(E)

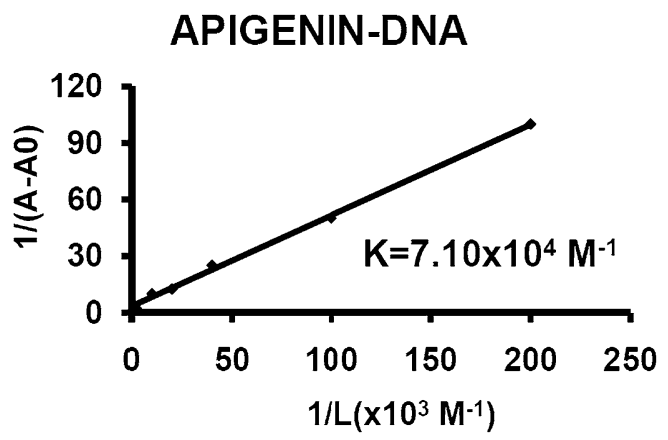

(B)

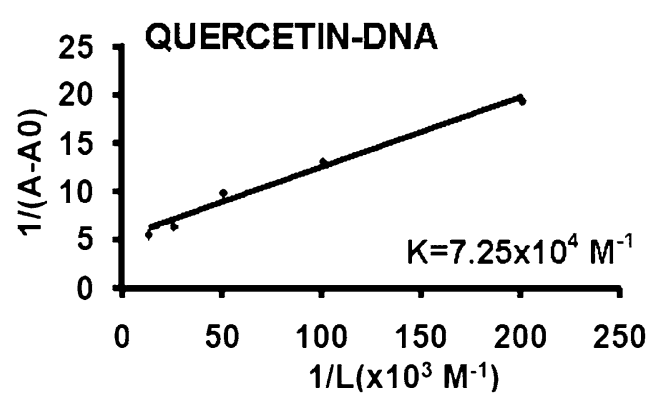

(D)

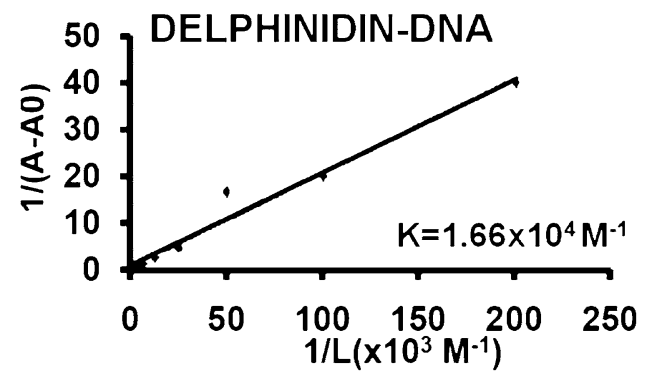

(F)

Fig. 6. The plot of $1 /\left(A-A_{0}\right) v s .1 / C$ and the binding constant $(K)$ for DNA and its flavonoid complexes where $A_{0}$ is the initial absorption of DNA $(260 \mathrm{~nm})$ and $A$ is the recorded absorption at different pigment concentrations $(0.005-0.3 \mathrm{mM})$ and final DNA concentration of $0.25 \mathrm{mM}$.

Table 1

Overall binding constants $(K)$ of flavonoid-DNA and flavonoid-RNA adducts

\begin{tabular}{lcc}
\hline Compound & \multicolumn{2}{c}{$K$, binding constant $\left(\mathrm{M}^{-1}\right)$} \\
\cline { 2 - 3 } & Flavonoid-DNA & Flavonoid-RNA \\
\hline Morin & $5.99 \times 10^{3}$ & $9.15 \times 10^{3}$ \\
Apigenin & $7.10 \times 10^{4}$ & $4.96 \times 10^{4}$ \\
Naringin & $3.10 \times 10^{3}$ & $1.14 \times 10^{4}$ \\
Quercetin & $7.25 \times 10^{4}$ & $4.80 \times 10^{4}$ \\
Kaempferol & $3.60 \times 10^{4}$ & $4.65 \times 10^{4}$ \\
Delphinidin & $1.66 \times 10^{4}$ & $9.47 \times 10^{4}$ \\
\hline
\end{tabular}




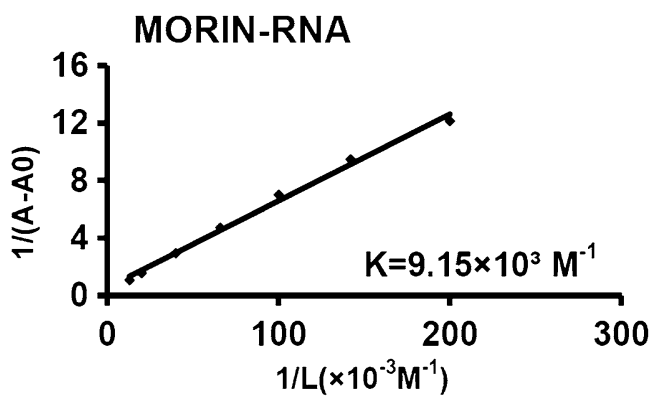

(A)

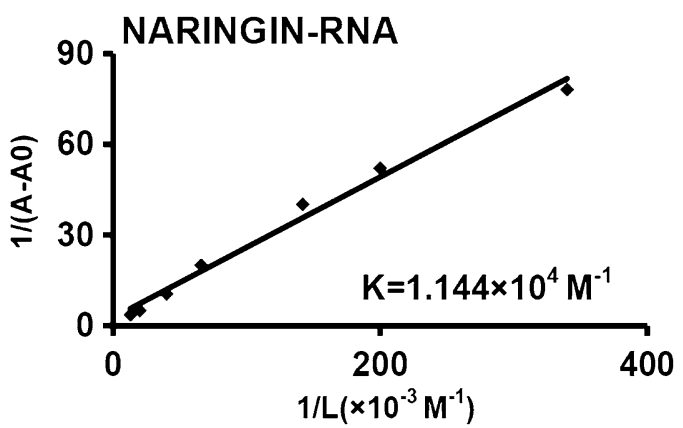

(C)

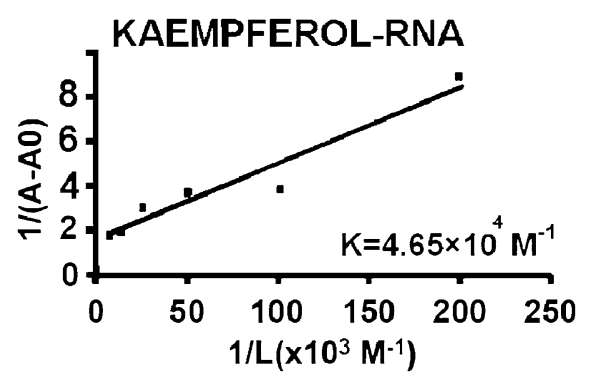

(E)

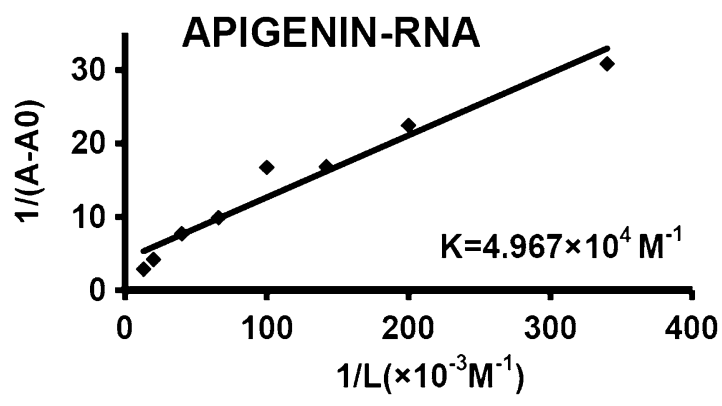

(B)

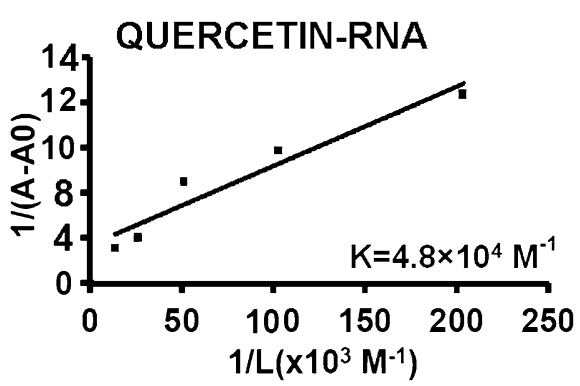

(D)

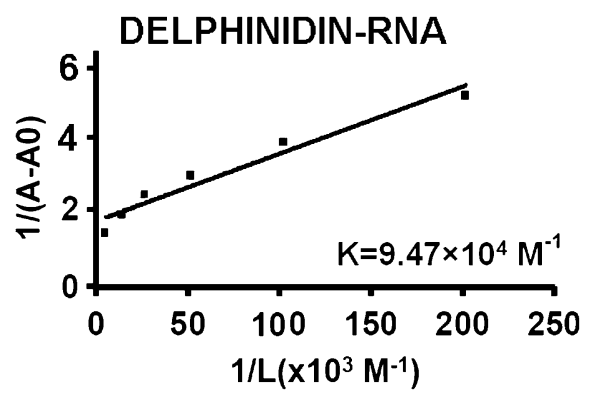

(F)

Fig. 7. The plot of $1 /\left(A-A_{0}\right)$ vs. $1 / C$ and the binding constant $(K)$ for tRNA and its flavonoid complexes where $A_{0}$ is the initial absorption of tRNA $(260 \mathrm{~nm})$ and $A$ is the recorded absorption at different pigment concentrations $(0.005-0.3 \mathrm{mM})$ and final tRNA concentration of $0.25 \mathrm{mM}$.

compounds as it has less hydroxyl groups ( 3 compared to 5 for morin and 8 for naringin) (Fig. 1), one can presume that it is less solvated and consequently susceptible to interaction with DNA and RNA more significantly. This would be in line with the suggestion made by Wang that myricetin (analogue of apigenin with $6 \mathrm{OH}$ groups) did not have influence on cell cycle arrest or cell number because it was more water-soluble than apigenin and other apigenin analogues [54].

\subsection{Antioxidant activity}

Burda et al. [55] have tested the antioxidant activity of morin, naringin and apigenin by applying the $\beta$-carotene/linoleic acid antioxidant activity assay and the $\mathrm{DPPH}^{\circ}$ antiradical activity method: in the case of the $\beta$-carotene/linoleic acid method: morin is a flavonol with a free hydroxyl group at the C-3 
Table 2

Antioxidant activity of flavonoids

\begin{tabular}{lcc}
\hline Compound & DPPH $^{*}$ method & $\beta$-carotene/linoleic acid method \\
\hline Morin & 96.5 & 63.5 \\
Apigenin & 0.7 & -78.8 \\
Naringin & 5.6 & 47.4 \\
Quercetin & $-6.73 \pm 0.08$ & $630 \pm 42$ \\
Kaempferol & $-2.09 \pm 0.10$ & $172 \pm 6$ \\
Delphinidin & $-8.86 \pm 0.28$ & $897 \pm 147$ \\
\hline
\end{tabular}

position. Therefore, the flavonol C-3 hydroxyl group is responsible for the high inhibition of $\beta$-carotene oxidation. Comparison of the antioxidant activity of flavonol aglycons with those of their glycosides or methyl derivatives showed that the blockage of the C-3 hydroxyl group resulted in a total loss of antioxidant activity. Glycosylation or methylation of other flavonol hydroxyls did not produce such an effect. That's why morin has higher antioxidant activity than naringin and apigenin (Table 2).

In the case of the DPPH' method: the flavonoids with hydroxyl group (flavone e.g. apigenin, flavanone e.g. naringin) or with the free hydroxyls only at C-5 and/or C-7 had no effect on scavenging free radicals. All flavonols with a free hydroxyl in the C-3-position (e.g. morin) which were very effective antioxidants, also had high ability to scavenge $\mathrm{DPPH}{ }^{*}$ radicals. Flavanones with a single bond at $\mathrm{C} 2-\mathrm{C} 3$, which have only one hydroxyl group in the B-ring at C-4', showed very low antiradical activity (naringin). Flavones and flavonols with a substituted hydroxyl group at the C-3 position, which have only a C-4' hydroxyl group in the B-ring showed distinctly higher activity; only apigenin showed no antiradical properties (Table 2). So the antioxidant activity is: morin $>$ naringin $>$ apigenin.

The results of antioxidant activity of quercetin, kaempferol and delphinidin measured by different methods [56-58] are presented in Table 2. Higher values for $\beta$-carotene bleaching method indicated less bleaching with increasing concentrations of compound added and therefore, higher antioxidant activity. Higher absolute values for antiradical activity by the $\mathrm{DPPH}^{\cdot}$ method indicated a higher concentration of DPPH $^{\cdot}$ needed to react with each micromolar of compound and, therefore, higher potential antioxidant activity. Compounds with three hydroxyl groups on the B ring of flavonoids (delphinidin) showed higher antioxidant activity. The loss of one hydroxyl group decreased activity slightly (quercetin), whereas the loss of two hydroxyl groups significantly decrased activity (kaempferol). Thus the antioxidant activity is delphinidin $>$ quercetin $>$ kaempferol (Table 2). From the previous results it is obvious that in general flavonoids have significant antioxidant activity.

Flavone smaller than flavonols and anthocyanidin (belongs to flavonoid class) can intercalate into DNA duplex and protects DNA from free radicals [46]. Flavonoids bind to DNA via both external and intercalative modes and can prevent DNA damage by scavenging free radicals. Addition of free $\mathrm{OH}$ radical into flavonoids is the key mechanism of antioxidant properties of these naturally occurring polyphenolic compounds. Flavonoids can chelate Fe cations and prevent free radical production in Fenton reaction, which are the major source of DNA damage. Flavonoids also bind other divalent cations such as $\mathrm{Cu}$ and prevent DNA oxidation from free radicals.

\section{Summary and future directions}

Flavonoids bind DNA and RNA via both intercalation and groove binding. The stabilities of the complexes formed are $K_{\mathrm{mor}}=5.99 \times 10^{3} \mathrm{M}^{-1}, K_{\mathrm{api}}=7.10 \times 10^{4} \mathrm{M}^{-1}$, and $K_{\mathrm{nar}}=3.10 \times 10^{3} \mathrm{M}^{-1}$, 
$K_{\text {que }}=7.25 \times 10^{4} \mathrm{M}^{-1}, K_{\text {kae }}=3.60 \times 10^{4} \mathrm{M}^{-1}$ and $K_{\text {del }}=1.66 \times 10^{4} \mathrm{M}^{-1}$ for DNA and $K_{\text {mor }}=9.15 \times 10^{3} \mathrm{M}^{-1}, K_{\text {api }}=4.96 \times 10^{4} \mathrm{M}^{-1}$, and $K_{\text {nar }}=1.14 \times 10^{4} \mathrm{M}^{-1}, K_{\text {que }}=4.80 \times 10^{4} \mathrm{M}^{-1}$, $K_{\text {kae }}=4.65 \times 10^{4} \mathrm{M}^{-1}$ and $K_{\text {del }}=9.47 \times 10^{4} \mathrm{M}^{-1}$ for RNA. Flavonoid complexation leads to a partial B to A-DNA transition, while RNA remains in A-conformation.

The ability of flavonoids to interact with free radicals when are associated with DNA via external binding or intercalative modes makes them strong antioxidants to protect DNA from harmful chemical reactions.

So far, we have only one report presenting the structural model for intercalation of apigenin and related compounds with DNA duplex [44]. Future studies should be focused on building possible models for different types of flavonoid-DNA or flavonoid-RNA complexes based on intermolecular distances and energy minimization in order to establish correlations between pigment binding mode and antioxidant activity that lead to prevent DNA damage.

\section{Acknowledgements}

We highly appreciate the financial supports from the Natural Sciences and Engineering Research Council of Canada (NSERC), the Agricultural University of Athens, Greece, and Azad University, Central Tehran Branch, Iran, for this work.

\section{References}

[1] M. Antolovich, P.D. Prenzler, E. Patsalides, S. McDonald and K. Robards, Methods for testing antioxidant activity, Anal. Crit. Rev. 127 (2002), 183-198.

[2] D. Boskou, Sources of natural phenolic antioxidants, Trends Food Sci. Technol. 17 (2006), 505-512.

[3] E. Middleton, C. Kandaswami and T.C. Theoharides, The effects of plant flavonoids on mammalian cells: Implication for inflammation, heart disease and cancer, Pharmacol. Rev. 52 (2000), 673-751.

[4] J. Torel, J. Cillard and P. Cillard, Antioxidant activity of flavonoids and reactivity with peroxy radical, Phytochemistry 25 (1986), 383-385.

[5] C. Rice-Evans, N.J. Miller and G. Paganga, Structure-antioxidant activity relationships of flavonoids and phenolic acids, Free Rad. Biol. Med. 20 (1996), 933-956.

[6] S. Burda and W. Olesze, Antioxidant and antiradical activities of flavonoids, J. Agric. Food Chem. 49 (2001), $2774-2779$.

[7] C.S. Yang, J.M. Landau, M.T. Huang and H.L. Newmark, Inhibition of carcinogenesis by dietary polyphenolic compounds, Ann. Rev. Nutr. 21 (2001), 381-406.

[8] W. Ren, Z. Qiao, H. Wang, L. Zhu and L. Zhang, Flavonoids: Promising anticancer agents, Med. Res. Rev. 23 (2003), 519-534.

[9] E. Middleton Jr. and C. Kandaswami, The impact of plant flavonoids on mammalian biology: Implications for immunity, inflammation and cancer, in: The Flavonoids: Advances in Research Since 1986, J.B. Harborne, ed., Chapman and Hall, London, 1994, pp. 619-652.

[10] B. Halliwell, R. Aeschbach, J. Loliger and O.I. Aruoma, The characterization of antioxidants, Food Chem. Toxicol. 33 (1995), 601-617.

[11] S. Fleschin, M. Fleschin, S. Nita, E. Pavel and V. Magearu, Free radical mediated protein oxidation in biochemistry, Roun Biotech. Lett. 5 (2003), 479-495.

[12] P.L. Kuo, Y.L. Hsu and C.C. Lin, The chemopreventive effects of natural products against human cancer cells, Int. J. Appl. Sci. Eng. 3 (2005), 203-214.

[13] G.M. Blackburn and M.J. Gait, Nucleic Acids in Chemistry and Biology, Chapter 8, Oxford University Press, Oxford, 1996, pp. 329-374.

[14] Y. Sakihama, M.F. Cohen, S.C. Grace and H. Yamasaki, Plant phenolic prooxidant activities: phenilics induced oxidative damage mediated by metals in plants, Toxicology 177 (2002), 67-80.

[15] T.B. Ng, F. Liu and Z.T. Wang, Antioxidant activity of natural products from plants, Life Sci. 66 (2000), 709-723.

[16] L.L. Marchand, Cancer preventive effects of flavonoids, Biomed. Pharmacother. 56 (2002), 296-301. 
[17] G.D. Carlo, N. Mascolo, A.A. lzzo and F. Capasso, Flavonoids: Old and new aspects of class of natural therapeutic drugs, Life Sci. 65 (1999), 337-353.

[18] J.J. Peterson, G.R. Beecher, A. Seema, S.A. Bhagwat, J.T. Dwyer, S.E. Gebhardt, D.B. Haytowitz and J.M. Holden, Flavanones in grapefruit, lemons, and limes: A compilation and review, J. Food Compos. Anal. 19 (2006), S74-S80.

[19] J.B. Harborne and C.A. Williams, Advances in flavonoid research since 1992, Phytochemistry 55 (2000), 481-504.

[20] L.H. Yao, Y.M. Jiang and J. Shi, Flavonoids in food and their health benefits, Foods Hum. Nutr. 59 (2004), 113-122.

[21] R.J. Williams, J.P. Spencer and C. Rice-Evans, Flavonoids: antioxidants or signalling molecules?, Free Radic. Biol. Med. 36 (2004), 838-849.

[22] S.L. Hsu, C.Y. Chen, W.H. Peng and K.W. Tsai, Luteolin suppresses inflammation-associated gene expression by blocking NF- $\kappa$ B and AP-1 activation pathway in mouse alveolar macrophages, Life Sci. 81 (2007), 1602-1614.

[23] Y. Lee, A.M. Boerboom, A. Westphal, W.V. Berkel, I. Rietjens and J. Aartz, Mechanism of EpRE-mediated gene transcription by flavonoids, Toxicol. Lett. 172 (2007), S68-S69.

[24] Y.J. Moon, X. Wang, M.E. Morris and M.E. Morris, Dietary flavonoids: Effects on xenobiotic and carcinogen metabolism, Toxicol. In Vitro 20 (2006), 187-210.

[25] S.W. Lee, G.S. Song, C.H. Kwon and Y.K. Kim, Beneficial effect of flavonoid baicalein in cisplatin-induced cell death of human glioma cells, Neurosci. Lett. 382 (2005), 71-75.

[26] M.A. Vargo, O.H. Voss, F. Poustka, A.J. Cardounel, E. Grotewold and A.I. Doseff, Apigenin-induced-apoptosis is mediated by the activation of PKC $\delta$ and caspases in leukemia cells, Biochem. Pharmacol. 72 (2006), 681-692.

[27] M. Ishikawa, S.I. Kanno, A. Shouji, R. Hirata and K. Asou, Effects of naringin on cytosine arabinoside (Ara-C)-induced cytotoxicity and apoptosis in P388 cells, Life Sci. 75 (2004), 353-365.

[28] S. Ramos, Effects of dietary flavonoids on apoptotic pathways related to cancer chemoprevention, J. Nutr. Biochem. 18 (2007), 427-442.

[29] G.R. Beecher, Overview of dietary flavonoids: nomenclature, occurrence and intake, J. Nutr. 133 (2003), 3248S-3254S.

[30] K. Robards and M. Antolovich, Analytical chemistry of fruit bioflavonoids, Analyst 122 (1997), 11R-34R.

[31] T. Walle, T.S. Vincent and U.K. Walle, Evidence of covalent binding of the dietary flavonoid quercetin to DNA and protein in human intestinal and hepatic cells, Biochem. Pharmacol. 65 (2003), 1603-1610.

[32] M. Lodovici, F. Guglielmi and P.D. Meoni, Effect of natural phenolic acids on DNA oxidation in vitro, Food Chem. Toxicol. 39 (2001), 1205-1210.

[33] M.R. Webb and S.E. Ebeler, Comparative analysis of topoisomerase IB inhibition and DNA intercalation by flavonoids and similar compounds: structural determinates of activity, Biochem. J. 384 (2004), 527-541.

[34] L.C. Wilms, P.C.H. Hollman, A.W. Boots and J.C.S. Kleinjans, Protection by-quercetin and quercetin-rich fruit juice against induction of oxidative DNA damage and formation of BPDE-DNA adducts in human lymphocytes, Mutat. Res. 582 (2005), 155-162.

[35] M.E. Reichmann, S.A. Rice, C.A. Thomas and P. Doty, A further examination of the molecular weight and size of desoxypentose nucleic acid, J. Am. Chem. Soc. 76 (1954), 3047-3053.

[36] R. Vijayalakshmi, M. Kanthimathi, V. Subramanian and B.U. Nair, DNA cleavage by a chromium (III) complex, Biochem. Biophys. Res. Commun. 27 (2000), 731-734.

[37] K. Nejedly, J. Chladkova, M. Vorlickova, I. Hrabcova and J. Kypr, Mapping the B-A conformational transition along plasmid DNA, Nucl. Acids Res. 33(1) (2005), 1-8.

[38] V.N. Potaman, Y.A. Bannikov and L.S. Shlyachtenko, Sedimentation of DNA in ethanol-water solution within the interval of B to A transition, Nucl. Acids Res. 8 (1980), 635-642.

[39] A.A. Ouameur and H.A. Tajmir-Riahi, Structural analysis of DNA interactions with biogenic polyamines and cobalt (III) hexamine studied by Fourier transform infrared and capillary electrophoresis, J. Biol. Chem. 279 (2004), 42041-42054.

[40] A.A. Ouameur, H. Malonga, J.F. Neault, S. Diamantoglou and H.A. Tajmir-Riahi, Taxol interaction with DNA and RNA: Stability and structural features, Can. J. Chem. 82 (2004), 1112-1118.

[41] J.J. Stephanos, Drug-protein interactions: Two-site binding of heterocyclic ligands to a monomeric hemoglobin, J. Inorg. Biochem. 62 (1996), 155-169.

[42] J.J. Stephanos, S.A. Farina and A.W. Addison, Iron ligand recognition by monomeric hemoglobins, Biochim. Biophys. Acta 1295 (1996), 209-221.

[43] Sh. Nafisi, M. Hashemi, M. Rajabi and H.A. Tajmir-Riahi, DNA adducts with antioxidant flavonoids morin, apeigenin and naringin, DNA Cell Biol. 27 (2008), 433-442.

[44] K.C. Bible, R.H. Bible, T.J. Kotte, P.A. Svingen, K. Xu, Y.P. Pang, E. Hadju and S.H. Kaufmann, Flavopiridol binds to duplex DNA, Cancer Res. 60 (2000), 2419-2428.

[45] C.D. Kanakis, P.A. Tarantilis, M.G. Polissiou, S. Diamantoglou and H.A. Tajmir-Riahi, DNA interaction with naturally occurring antioxidant flavonoids quercetin, kaempferol and delphinidin, J. Biomol. Struct. Dyn. 22 (2005), 719-724.

[46] J. Dean, Flavone: The molecular and mechanistic study of how a simple flavonoid protects DNA from oxidative damage, $\mathrm{PhD}$ thesis, East Tennessee State University, USA, 2003.

[47] D. Freifelder, Physical Biochemistry, Chapter 15, W.H. Freeman and Company, New York, 1976. 
[48] J.B. Lambert, H.F. Shurvell, D.A. Lightner and R.G. Cooks, Organic Structural Spectroscopy, Chapters 10 and 11 , Prentice-Hall, New Jersey, 1998.

[49] Sh. Nafisi, A. Shadaloi, A. Feizbakhsha and H.A. Tajmir-Riahi, RNA binding to antioxidant flavonoids, J. Photochem. Photobiol. B 94 (2009), 1-7.

[50] C.D. Kanakis, P.A. Tarantilis, M.G. Polissiou and H.A. Tajmir-Riahi, Interaction of antioxidant flavonoids with tRNA: Intercalation or external binding and comparison with flavonoid-DNA adducts, DNA Cell Biol. 25 (2006), 116-123.

[51] E. Taillandier and J. Liquier, Infrared spectroscopy of DNA, Methods Enzymol. 211 (1992), 307-335.

[52] H.A. Tajmir-Riahi, J.F. Neault and M. Naoui, Does DNA acid fixation produce left-handed Z-structure?, FEBS Lett. 370 (1995), 105-108.

[53] J. Kang, Z. Li and X. Lu, Electrochemical study on the behavior of morin and its interaction with DNA, J. Pharmaceut. Biomed. Anal. 40 (2006), 1166-1171.

[54] W. Wang, P.C. Vanalstyne, K.A. Irons, S. Chen, J.W. Stewart and D.F. Birt, Individual and interactive effects of apigenin analogs on G2/M cell-cycle arrest in human colon carcinoma cell lines, Nutr. Cancer 48 (2004), 106-114.

[55] S. Burda and W. Oleszek, Antioxidant and antiradical activities of flavonoids, J. Agric. Food Chem. 49 (2001), $2774-2779$.

[56] G. Cao, E. Sofic and R.L. Prior, Antioxidant and antiprooxidant behaviour of flavonids: Structure-activity relationships, Free Rad. Biol. Med. 22 (1997), 749-760.

[57] H. Wang, G. Cao and R.L. Prior, Oxygen radical absorbing capacity of anthocyanins, J. Agric. Food Chem. 45 (1997), 304-309.

[58] L.R. Fukumoto and G. Mazza, Assessing antioxidant and prooxidant activities of phenolic compounds, J. Agric. Food Chem. 48 (2000), 3597-3604. 


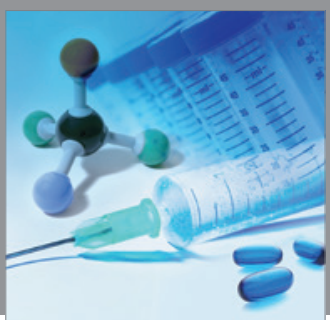

International Journal of

Medicinal Chemistry

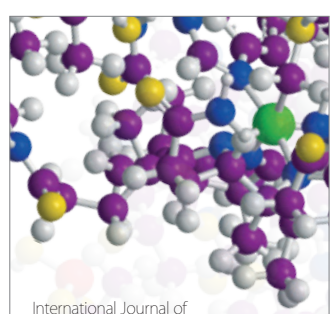

Carbohydrate Chemistry

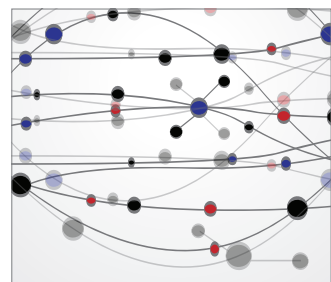

The Scientific World Journal
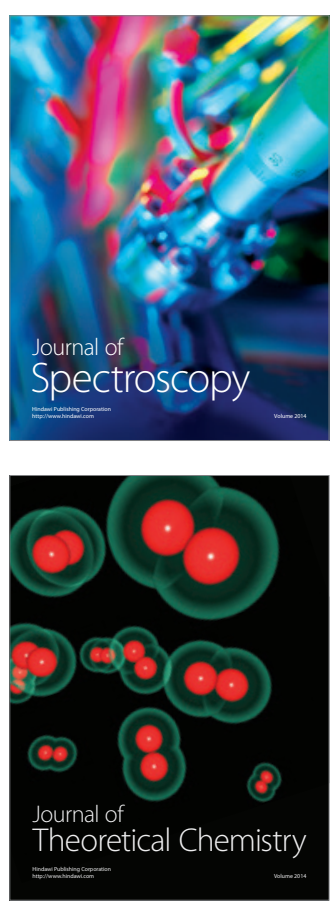
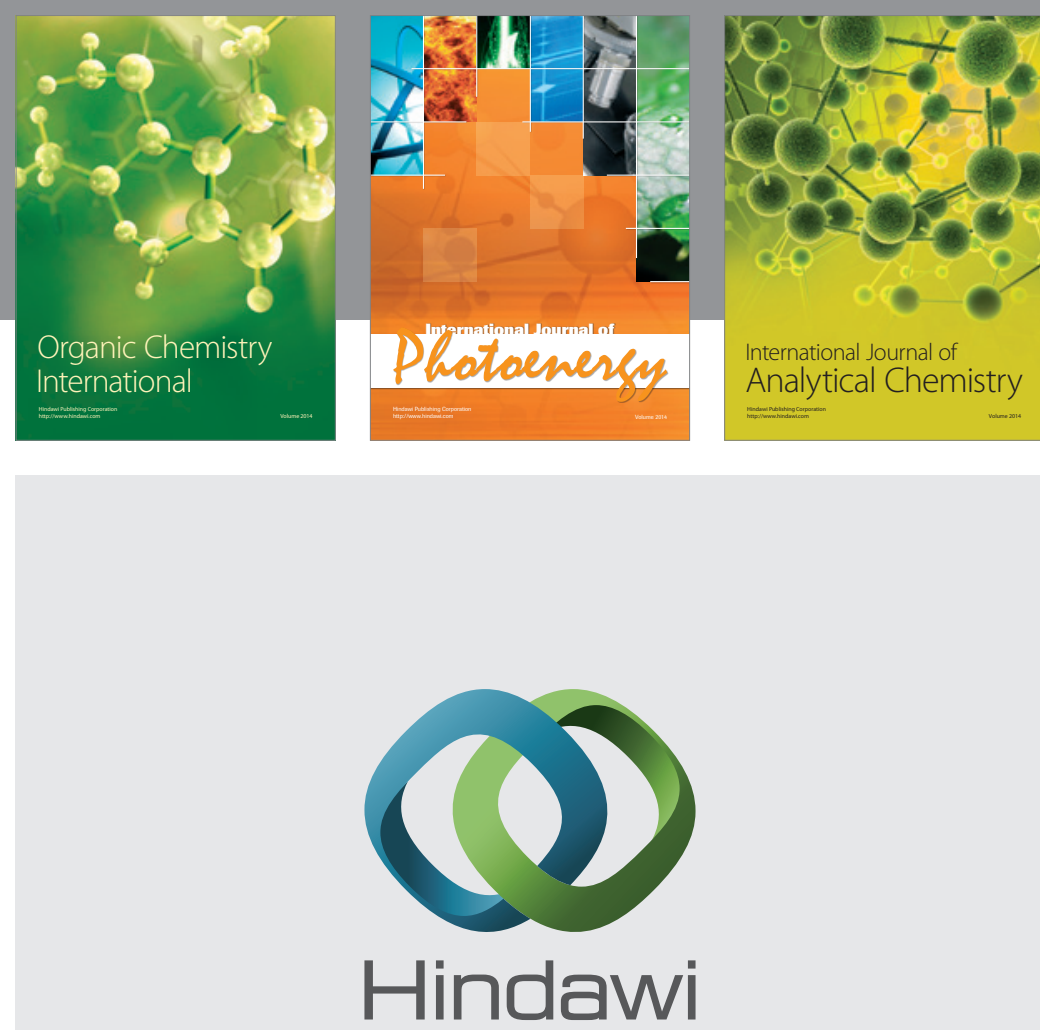

Submit your manuscripts at

http://www.hindawi.com
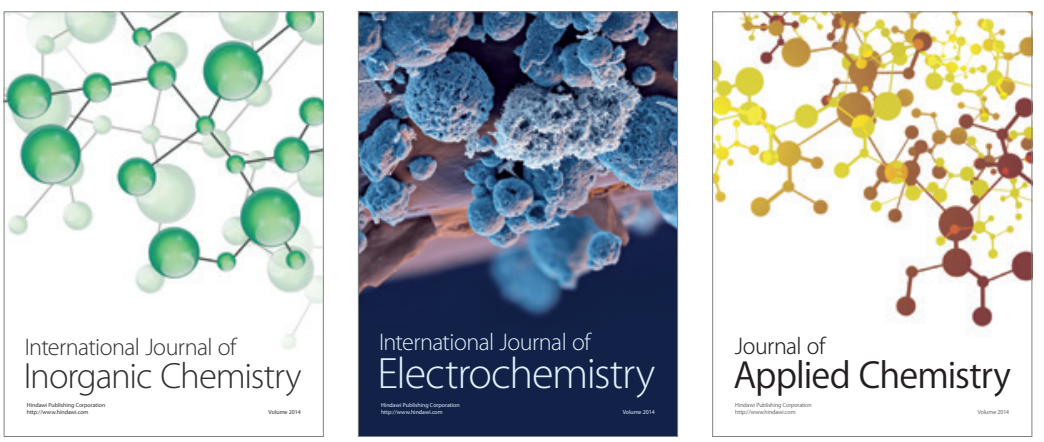

Journal of

Applied Chemistry
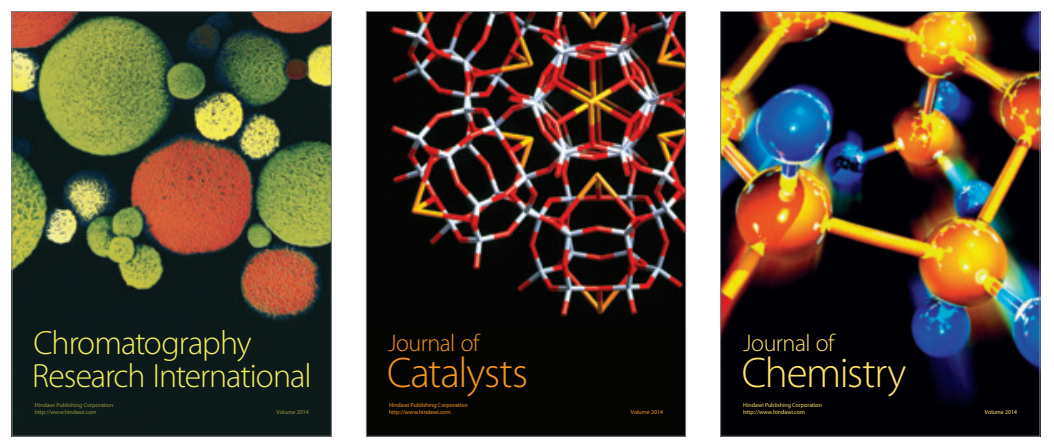
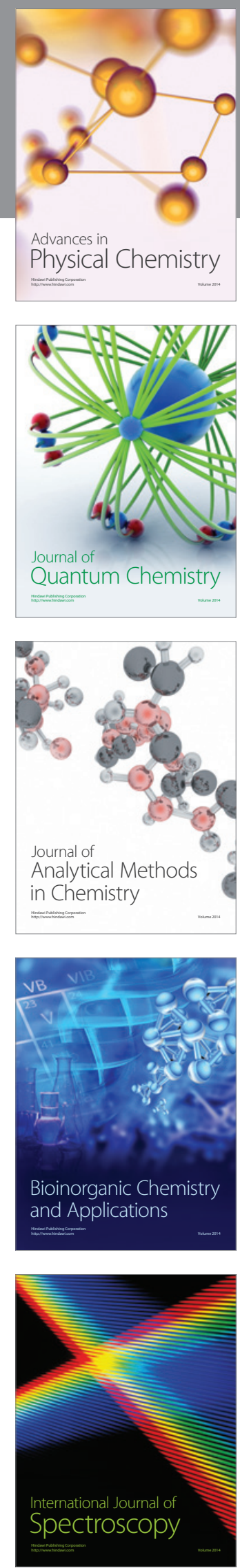